Fithra Faisal Hastiadi* Waseda University

Recibido: 3 de agosto de 2011

Concepto de evaluación: 3 de octubre de 2011

Aprobado: 25 de octubre de 2011

*Graduate School of Asia-Pacific Studies (GSAPS), Waseda University Nishi-Waseda, Shinjukuku, Tokyo, JAPAN. E-mail: fithra@asagi.waseda.jp; fithra_faisal@yahoo.com

\section{The determinants of east asian regionalism}

\section{ABSTRACT}

East Asia has been experiencing an epic progress of regionalism over the last decade with China, Japan, and Korea (CJK) as the most prominent actors. Regionally speaking, East Asia has been nurtured by a market-driven expansion of trade and foreign direct investment (FDI) that leads the bottomup regionalism process. However, this paper argues that the bottom-up process alone is not enough since a more institutionalized approach is needed. From a static panel data simulation, it is found that sound transportation infrastructure, good governance, competitive taxation policies, sizeable markets, good education, democracy and the trend towards industrialization are the main factors that serve as building blocks for East Asian regionalism.

Keywords: regionalism, panel data, East Asia, trade

JEL Clasification: C33, R13, N15.

\section{Los determinantes del regionalismo de Asia Oriental}

\section{RESUMEN}

Asia oriental ha experimentado un progreso épico del regionalismo en la última década, con China, Japón y Corea (CJK), como los actores más destacados. Regionalmente hablando, Asia oriental ha sido alimentado por una expansión impulsada por el mercado del comercio y la inversión extranjera directa (IED) que lidera el proceso de regionalismo, de abajo hacia arriba. Sin embargo, este trabajo sostiene que el proceso de abajo hacia arriba por sí solo no es suficiente, ya que se necesita un enfoque más institucional. Desde un panel de simulación estática de datos, se comprueba que la infraestructura de transporte, el buen gobierno, políticas de competencia fiscal, los mercados de gran envergadura, buena educación, la democracia y la tendencia hacia la industrialización son los principales factores que sirven como bloques de construcción para el regionalismo de asia oriental.

Palabras clave: regionalismo, data panel, asia oriental, comercio Clasificación JEL: C33, R13, N15. 


\section{INTRODUCTION}

East Asian countries cannot escape from the fact that they are now being more integrated than before. Regionally speaking, East Asia has been nurtured by a market-driven expansion of trade and foreign direct investment (FDI). Kawai (2007) described the data of a heavily expanded trade and FDI in the region over the past two decades.

The share of intraregional trade of ASEAN Plus Three (APT) has been increasing dramatically over the last decade. The share is now reaching a staggering figure as it almost reaches 60 per cent. In comparison with the figure in early nineties, it can be concluded that East Asia is becoming more interconnected, and all of these facts have led the well known bottom-up process of regionalism.

Unfortunately, the bottom up process alone is not enough. A more institutionalized approach is needed in order to make the regionalism solid and sustainable. Although the leaders of ASEAN +3 countries have repeatedly held meetings, the topdown process in East Asia has still not reached its potentials. It is fair to say that, as Capannelli (2011) argues, the increased economic interdependence in East Asia over the last few decades has been heavily dominated by the markets rather than government policies. Coordinated intergovernmental initiatives for cooperation, including the creation of regional institutions, have lagged behind. Different from Europe, economic integration in Asia has emerged without a clear strategy for creating a unity across the countries in the region (Asian Development Bank, ADB, 2008; Drysdale, 2006; Kawai, 2005; Petri, 2006; Soesastro, 2006).

Feng and Genna (2003) argued that homogeneity of domestic institutions is needed to go together with the regional integration process. Moreover, they pointed out inflation, taxation and government regulation as representing factors for the economic institutions. Another variable that might enhance integration is population, as already identified by Tamura (1995). He argued that large population is a catalyst for integration due to economic agglomeration. Scholars like Milner and Kubota (2005) even pointed out democracy as an important factor that could foster regionalism. Their empirical work on the developing countries from 1970 to 1999 showed that regime change toward democracy was associated with trade liberalization and regionalization.

Based on the aforementioned, knowing the factors that determine the formation of regionalism (top-down process to match the existing bottom-up process) is becoming more and more crucial. Given this fact, this chapter tries to identify the variables that provide a clear path for the formation of East Asian Regionalism (EAR). Thus, a unified East Asia could accelerate the momentum of overall trade liberalization and boost regional economic growth.

The last part of this chapter is organized as follows. The second section studies the basic concepts. The third section covers materials and methods. The fourth section examines the results, and the last section presents some concluding remarks.

\section{BASIC CONCEPTS}

\section{Democracy and regionalism}

Many scholars believe that the types of regime can influence the choice to join or not to join the free trade scheme. However, whether or not democracy promotes free trade still finds some ambiguous arguments among scholars. Given the global trend toward democracy, the answer is of more than pedagogical interest. If democracy indeed promotes free trade, then the spread of democracy should reinforce regionalism, because it creates a path to open the markets for poor countries that have historically lacked market access. However, if democracy can lead to protection, the formation of regionalism will face substantial problem. Either way, understanding and predicting the future of regionalism requires an understanding of the democracy and trade policy relationship.

Milner and Kubota (2005) argue that democratization, which implies a size increase in the 
selectorate, have a direct consequence in changing the calculations of political leaders about the optimal level of trade barriers. They see that democratization induces the adoption of trade policies that better promote the welfare of consumers/voters at large, which implies trade liberalization in this context. Although the interest of protectionist groups remain important as the dynamic of democracies, other groups preferring lower trade barriers become more important for political leaders since they are now part of the selectorate upon which leaders can depend for their political survival.

The work of Grossman and Helpman (1994) on the political economy of protection tells somewhat a different story compared to the aforesaid. They argue that if rational policymakers (government, parliament) maximize a weighted sum of campaign contributions and general welfare, the equilibrium tariff depends on the relative weights placed on each one in the government's objective function. To the extent that special interest groups are more active in a democracy (Olson, 1982), they might constitute a greater weight, and therefore a greater level of democracy would lead to higher trade barriers. Conversely, political competition generated in an active democracy might imply that policymakers weight more heavily -in general- versus special interest welfare. These models are silent as to which influence might dominate; however, empirical work testing the protection for sale model has yielded results that are supportive of a positive linkage between democracy and trade (Mitra, Thomakos \& Ulubasoglu, 2002).

To simulate the logic, the study goes through the juggernaut and Domino framework which was first introduced by Baldwin (2006). Although it is known best for explaining the behavior of exporter and importer, it also serves well when it comes to politics. The main similarity would be the involvement of actors that seek a politically optimal point (equilibrium point). Those actors are:(a) policy makers, (b) anti free-trade actors, and (c) pro-trade actors. Moving on to the scenario where anti freetrade actors have dominant lobbying power that influences the whole system, pro-trade actors will try their best to ensure their activities stay safe. To do so, the anti free-trade actors need to lobby the policy makers to impose high tariff by reciprocally giving the policy makers bigger sound prognosis of consumer welfare. Naturally, the pro-trade activists would resist any kind of tariff hikes. For the anti trade actors, the given characteristic means lobbying cost. Since the first scenario assumes anti trade actors to have ample amount of resources to handle the cost, the policy makers will then be stirred to set cuts on sanction.

The number of anti trade actors is determined by a free entry condition which is a function of the tariff. Higher tariff rates will lead to increasing numbers of anti trade actors as they face lesser barriers to entry. The tariff itself is determined by the actions of policy makers when it optimizes a 'politically realistic objective function'. The objective function here is defined as way to maximize individual preferences. The intersection of a politically realistic objective function with the free-entry conditions provides a set of combinations where policy makers are choosing the politically-optimal rule while allowingthe anti trade actors to enter the game up to the point of no return.

Reciprocal talks (taking the form of negotiation between anti trade actors and policy makers) will have a direct impact for a politically optimal tariff. This scenario will shift down the objective function of the policy makers since they have a new set of optimal rule. The shifting will -in turndrive some pro-trade actors to be marginalized as they face increasing numbers of anti trade actors, which also means increasing lobbying power against them. This situation will decrease the cost of lobbying since the political resistance from the pro-trade actors is decreasing linearly with the leaping size of anti trade actors. As far as Baldwin's juggernaut effect is concerned, the political economy forces driving the effect are strengthened by the tendency of special interest groups to fight harder to secure gains. For them, joining the anti trade scheme will give new commercial opportunities. Having said this, the higher tariff may play a particularly important role in generating new 
anti-trade political economy activity. Doing another reciprocal talk is cheaper now, resulting to further hikes on tariff. The cycle repeats itself until new equilibrium is met (the juggernaut effect). As Geddes (1995) summarizes:

Until recently, it was widely accepted that democracies, especially fragile, uninstitutionalized new democracies have difficulty carrying out economic liberalization because its costs make it unpopular and hence politically suicidal to elected officials. Consequently, it was argued, authoritarian governments should be more capable of initiating and sustaining major economic reforms.

The effects of democracy on trade can also be determined by the characteristics of the voters. In his work on the political economy of trade, Mayer (1984) produces interesting findings concerning the unique characteristics of voters by using the Heckscher-Ohlin framework (two factors and two sectors). The findings emphasize on the endowment of median voter. If the median voter is well-endowed with labor, they will support imports of capital intensive goods but oppose imports of labor-intensive goods. On the other hand, if the median voter is well endowed with capital relative to their national mean, then they will support imports of labor-intensive goods, but oppose imports of capital-intensive goods. To correspond with Mayer's work, Dutt and Mitra (2002) explain that inequality raises trade barriers in capital rich countries and lowers them in capital scarce ones. Besides, left-wing governments adopt more protectionist policies in capital-rich countries, but more free trade policies in labor-rich economies with right-wing governments.

\section{Good governance and regionalism}

Until recently, the development literature put some excessive study on the terms governance and good governance. Bad governance, as the antithesis of good governance, is often regarded as a major root that creates all sources of problem. Major donors and international financial institutions are increasingly basing their aid and loans on the condition that reforms ensuring good governance are undertaken.

The concept of governance is not new. It is as old as human civilization. According to the United Nations Economic and Social Commission for Asia and the Pacific (UNESCAP, 2010), governance means: the process of decision-making and the process by which decisions are implemented (or not implemented). Governance can be used in several contexts such as corporate governance, international governance, national governance and local governance. Given the fact that governance is the process that involves decision-making and implementing, any analysis concerning governance should focus on the actors -formal and informal- that are drawn in the process.

Bringing the concept to practicality, government is deemed as one of the actors in governance. Other actors involved in governance vary depending on the level of government that is under discussion. In rural areas, for example, other actors may also include influential landlords, associations of peasant farmers, cooperatives, non-governmental organizations (NGOs), research institutes, religious leaders, finance institutions, political parties, the military etc. The situation in urban areas is much more complex. At the national level, in addition to the actors above, media, lobbyists, international donors or multi-national corporations may play a role in decision-making or in influencing the decisionmaking process.

All actors other than government and the military are put into one pot as a part of the 'civil society.' Although formal decisions are delivered and implemented at the national level by formal government structures, informal decision-making structures, such as 'kitchen cabinets' or informal advisors may exist. Corrupt practices are regarded as an influential factor determining such informal decision-making process. 
To be more specific, UNESCAP classifies good governance into eight (8) major characteristics. It is participatory, consensus-oriented, accountable, transparent, responsive, effective and efficient, equitable and inclusive, and follows the rule of law. It assures that corruption is minimized, the views of minorities are taken into account and that the voices of the most vulnerable in society are heard in decision-making. It is also responsive to the present and future needs of society.

In the relation with regionalism, various studies have demonstrated that governance is crucial for regionalism. Adam Smith (1776) noted that private contracting is an important factor for the mutually beneficial exchanges that promote specialization, innovation and growth, which are also the main factors for the gains from free-trade leading to regionalism.

Bolaky and Freund (2004) demonstrate that regulatory quality influences the interaction between trade and economic growth. They also argue that countries with excessive regulations do not get benefit from trade. The argument is relatively simple: Trade only benefits countries that have relatively low adjustment costs. In other words, countries that are facing low cost for reallocation of labor and capital -from the import-competing sector to the exports sector- will get high benefit from trade. On the other hand, countries with too much regulation may face a relatively rigid economic structure. In this case, production factors are facing difficulties in moving to the sectors where large welfare gains can be achieved. The economy may eventually end-up in a situation where trade does not have a beneficial impact on the allocation of resources within and between sectors. Furthermore, excessive regulations may encourage a country to produce goods for which it has no comparative advantage or the terms of trade have been unfavorable over recent decades.

Moreover, Fisman and Sarria-Allende (2004) find out two different outcomes for industries in countries that are (a) having or (b) not having excessive regulations. In responseto shocks, industries with high tariff barriers expand the existing firms while industries with low-entry barriers create new firms. In addition, countries facing high entry barrierstend to have only a few large firms -and industries are characterized by large sales turnover-, while countries with low entry barriers have many smaller firms. Thus, their results suggest that regulations create distortion in industrial structure, increase industrial concentration, and influence the amount of participants to an industry in case of external shocks. Similarly, Klapper, Laeven and Raghuram (2004) examine data on firms in Western and Eastern Europe and discover that entry regulations lead to less entry, especially in industries with naturally high-entry barriers. Furthermore, they find that excessive regulations deter the investment related to labor-intensive industries.

\section{Transport infrastructure and regionalism}

Good infrastructure -especially transport infrastructure such as roads, railways, and ports- will provide steadiness and assuredness in making trade investment in a country. Besides, solid infrastructure tends to lower the cost of trade and leads to sustainable intra-trade and investment. Thus said, it lays foundation for the formation of regionalism.

According to the World Trade Organization, WTO (2004), this sector is very crucial for moving goods and services from exporting to importing countries. Poor transport infrastructure or inefficient transport services are reflected in higher direct transport costs and longer time of delivery, while an improvement in the infrastructure of a country lowers the costs of trading. A study conducted by Limão and Venables (2001) shows that if there is an improved infrastructure in a country -moved from median point to top $25 \%$ of the total countries being surveyed-, it will cause a significant reduction on transportation cost up to 481 kilometers of overland travel and 3,989 kilometers of travel by sea. The shift of improvement will also causean increased volume of trade by $68 \%$, which is equivalent 
to being 2,005 kilometers closer to other countries. Meanwhile, countries facing inefficient transport services will experience higher overall transport costs. Poor quality of infrastructure increases total transport costs as it increases direct transport costs and the time of delivery. A study conducted by Wilson, Mann and Otsuki (2005) demonstrates that transport costs and lack of infrastructure wear down the potential income of local producers. The study performed by WTO (op. cit.) recognizes the negative impact of a lack of infrastructure on domestic income. Transportation infrastructure has been proved to have a pronounce effect on trade as it channels through the effect on the comparative advantage to trade of a country.

Yeaple and Golub (2002) make quantification that explains to which extent the difference in government infrastructure is affecting the existing Total Factor Productivity (TFP) at the sectoral level. They found that road infrastructure provision contributes as a significant factor in productivity growth of a sector and production specialization of a country. Moreover, the road infrastructure turns out to be significant not only as a factor affecting productivity growth in the transportation equipment sector, but also as a factor influencing the process of specialization in the production of textiles and apparel.

\section{Industrialization and regionalism}

By definition, industrialization means the process whereby a society or country (or region) transforms itself from a primarily agricultural society into one based on the manufacturing of goods and services. Individual manual labor is often replaced by mechanized mass production and craftsmen are replaced by assembly lines. Characteristics of industrialization include the use of technological innovation to solve problems as opposed to superstition or dependency upon conditions outside human control -such as the weather-as well as more efficient division of labor and economic growth. Industrialization is a historical phase and experience.
It is the overall change in circumstances accompanying the movement of population and resources from primary production activities to manufacturing production and associated services. In relation with regionalism, industrialization in developing countries creates mechanization for the parts and components that are being channeled from the developed countries. Regionally speaking, the industrialization process will help to enhance the region like a factory for the overall product fragmentation process. For East Asia, the example of Japan's production networks to the Southeast Asian countries can be taken into account Japan is widely known as the producer of highly value added engine parts and components, but actuaIly, the entire production process includes several South-East Asian countries: Indonesia is responsible for assembling gasoline engines and horns; Philippines specializes in making transmission and combination meters; Malaysia takes part to assemble engine parts and condensers; Thailand assembles diesel engines and air conditioning systems. This entire process of production networks is spurred by the industrialization in the South-East Asian countries (Watanabe, 2008).

\section{Population and regionalism}

Big population serves well not only for the demand for the goods from trade but also as supply of labor for the industrialization process. Indeed, it creates sustainable paths toward regionalism. Looking at the literature, the effect of population on trade is a bit equivocal.

Matyas (1997) finds that population has the positive tendency of raising trade volumes and the level in which it produces gains from specialization. On the other hand, Dell Ariccia (1999) finds a negative relation between population and the volume of trade. In addition, Bergstrand (1989) reports positive effect of gross domestic product (GDP) per capita on trade. He describes a negative GDP per capita coefficient in a way that the product group which is subject to the estimation is not 
capital intensive but labor intensive. Since higher population numbers decrease GDP per capita on a labor intensive basis, it can be seen a negative relationship between population and trade flows.

According to Nuroglu (2010) who studies the six big economies of the Organization of the Islamic Conference (OIC), the impact of population on trade will differ as it depends on the length of period of estimation (short-term vs. long-term). In the short run, population may have a positive impact on trade flows as it may raise the number of labor force, the level of specialization, and imply more products to export. However, in the long run, a bigger population has more possibilities to decrease income per capita, which make every individual to be poorer, and, therefore, it may cause production and exports to decrease. In addition, lower income per capita tends to decrease the demand for imports as well. Having said this, different results across period and region can be seen when measuring the effect of population on trade. Hence, it creates different conclusions.

\section{Education and regionalism}

Policies concerning enhancement in the field of education have long been known and have played a significant role in development. A high-quality human resource development is regarded as the genuine product of education that can improve any strategy related to competitiveness. That being said, good education is the key to reach economic growth and to escape from poverty.

Some developing countries have been successful in attracting FDI due to qualified human skills. In the East Asian context, the sound policy that promotes education can eventually diminish income gaps between the Northeast and Southeast Asian countries. The fact that product fragmentation is becoming a trend in this region also serves to the regional convergence. As stated by Jones and Kierzkowski (2001), fragmentation increases the wage rate in countries where labor is a relatively abundant production factor, while it lowers the wage rate in countries where capital is abundant. This eventually equalizes the wage rate between two countries in the long term. This equalization in wage is true if the educational gap among the countries becomes reduced and less significant.

\section{METHODOLOGY}

This essay employs a fixed effect model in panel data. The model can be specified as follows:

$Y_{i t}=\mathbf{X}_{i t} \beta+\lambda_{t}+\eta_{i}+\varepsilon_{i t} t=1, \ldots, T i=1, \ldots, N$

$\lambda_{t}$ and $\eta_{i}$ are time and individual specific effects respectively, $x$ is a vector of the explanatory variables, (i) is the time component of the panel, $(\mathrm{N})$ is the cross-section dimension (or the number of cross-section observations), and N x T is the total number of observations. The procedure consists in running the models in order to have a consistent estimator for the $\beta$ coefficients, and the model (fixed or random) choice depends on the hypothesis assumed for the relationship between the error-term $\left(\varepsilon_{i t}\right)$ and theregressors $\left(x_{i t}\right)$. The static panel data analysis developed in the empirical section of the paper was based on two basic panel models: the fixed (FE) and the random (RE) effect models. The FE estimator uses a transformation in order to remove the unobserved effects $(\alpha i)$ and any time-constant explanatory variable. A general representation of a FE model is:

$y_{i t}=\beta_{i} x_{i t}+\alpha_{i}+\varepsilon_{i t}$

Where $i=1, \ldots . N$ and $t=1, \ldots T$, where $(\mathrm{x})$ represents the explanatory variables, $(y)$ is the dependent variable and $\left(\varepsilon_{i t}\right)$ the error term.

If the average over time is considered:

$\bar{y}_{i t}=\beta_{i} \bar{x}_{i t}+\alpha_{i}+\bar{\varepsilon}_{i t}$

Subtracting (14) from (15) for each (t): 


$$
\begin{aligned}
& y_{i t}-\bar{y}_{i t}=\beta_{i}\left(x_{i t}-\bar{x}_{i t}\right)+\varepsilon_{i t}+\bar{\varepsilon}_{i t} \\
& \text { or } \hat{y}_{i t}=\beta_{i} \hat{x}_{i t}+\hat{\varepsilon}_{i t}
\end{aligned}
$$

The FE transformation is called the within transformation and the FE estimator (or the within estimator), which is the ordinary least square (OLS) estimation of equation (4a), the pooled OLS. Under the assumption of strict exogeneity for the explanatory variables $\left(\mathrm{E}\left(\varepsilon_{i t} / x_{i t}, \alpha_{i}\right)=0\right)$ the FE estimator is unbiased. If any explanatory variable is constant over time for all (i), it is swept away by the FE transformation $\left(\hat{x}_{i t}=0\right)$ the OLS estimation by $\mathrm{FE}$ also requires that the errors are homosedastic and serially uncorrelated over time.

The RE estimator is more adequate if it is assumed that the unobserved effect is not correlated with all the explanatory variables, and the estimation is carried on by a generalized least square (GLS) estimation. The equation representing the RE model is:

$y_{i t}=\beta_{0}+\beta_{\mathrm{i}} x_{i t}+\alpha_{\mathrm{i}}+\varepsilon_{\mathrm{it}}$

If the unobserved effect $\left(\alpha_{i}\right)$ is thought as uncorrelated with each explanatory variable $\left(x_{i t}\right)$, using a transformation (FE estimator) to eliminate $\left(\alpha_{i}\right)$ will result in inefficient estimators. Estimation of equation (5) for $\left(\alpha_{i}\right)$ uncorrelated with the explanatory variables is the RE model. If the composite error terms are defined as ( $\left.v_{\text {it }}=\alpha+\varepsilon\right)$, equation [5] can be written:

$y_{i t}=\beta_{0}+\beta_{i} x_{i t}+\mu_{i t}$

In this case, it is necessary to remember that $\left(u_{i t}\right)$ are serially correlated over time and the pooled OLS estimator is not the choice since it ignores the positive serial correlation, and the idea is to use the GLS to take into account to resolve the serial correlation problem. The GLS estimation will be a pooled OLS estimation of the transformed model, which can be represented as follows:

$$
\begin{gathered}
y_{i t}-\lambda \bar{y}_{i}=\beta_{0}(1-\lambda)+ \\
\beta_{i}\left(x_{i t}-\lambda \bar{x}_{i t}\right)+\left(u_{i t}-\lambda \overline{u_{i}}\right)
\end{gathered}
$$

$0<\lambda<1$

Where $\lambda=1-\left[\sigma_{\varepsilon}^{2}\left(\sigma_{\varepsilon}^{2}+T \sigma_{\alpha}^{2}\right)\right]$ for $\left(\hat{x}_{i t}=0\right)$

One of the advantages of using such transformation and the RE model is that it allows explanatory variables that are constant over time. By examining equation (1), one can relate the RE estimator (pooled OLS known as POLS) and FE where the POLS is obtained for the case where $\lambda=0$ (the unobserved effect, $\alpha i$ is not important) while the $\mathrm{FE}$ is the estimator for $\lambda=1$. The choice between the FE and the RE estimators is based on whether the unobserved effects $(\alpha i)$ can beconsidered as parameters to be estimated, or as an outcome of a random variable, suggesting the use of aFE or a RE model respectively. Since the time period (1998-2007) exceed the individual observations (Indonesia, Malaysia, Thailand, Philippines, China, Japan and Korea), the fixed effect model is considered the most appropriate method (Nachrowi \& Usman, 2008). Thus said, this essay formulate specific model as follows:

$$
\begin{aligned}
& \text { Open }_{i t}=\alpha+\beta X_{i t}+\gamma_{1} W_{1 t}+\gamma_{2} W_{2 t}+\gamma_{3} W_{3 t}+ \\
& \ldots+\gamma_{N} W_{N t}+\delta_{1} Z_{i 1}+\delta_{2} Z_{i 2}+\delta_{3} Z_{i 3}+\ldots+\delta_{t} Z_{i T}+\varepsilon_{\mathrm{it}}
\end{aligned}
$$

Following Hastiadi (2010) and Hastiadi (2011), the formula can be defined as:

\section{Where:}

$$
\begin{aligned}
& \text { Open }_{\text {it }}=\text { Regionalism for time } t \text { and country } \mathrm{i} \\
& \mathrm{X}_{\mathrm{it}}=\text { Independent Variables (ASEAN4 + CJK's }
\end{aligned}
$$




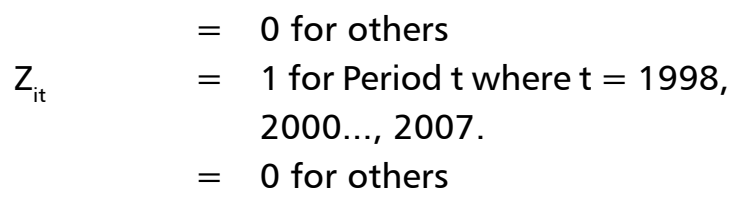

The following are the explanations for the variables as it is replicated from Hastiadi (2010; 2011):

(a) the study uses the proxy of trade openness (net export per GDP) for regionalism. The variable of openness is used to represent regionalism, since regionalism creates openness to some sectors of economy. Openness here functions as a dependent variable that is determined by some independent variables. (b) Railways as transported goods (million ton $/ \mathrm{km}$ ) is used to explain physical infrastructure readiness. Pairing up with this variable is the gross school enrolment rate, which serves as the basis for human capital infrastructure. Gross enrollment ratio is the ratio of total enrollment, regardless of age, to the population of the age group that officially corresponds to the level of education shownSound infrastructure (both physical and human) will provide steadiness and assuredness in making investment among members. In other words, good infrastructure will only lead to a sustainable intra-trade and investment that serve as the basis of EAR. (c) Democracy is measured by means ofthe index of democracy produced by Polity IV project data set. Democratization is expected to open-up new avenues of support for free trade vis-à-vis regionalism. (d) The next variable is the taxation policy, whereby the higher the rate, the more it will diminish the prospects of EAR. (e) Another meaningful variable is governance, which is measured by the six governance indicators estimated by Kaufmann, Kraay and Mastruzzi (2008). These indices describe various aspects of the governance structures of a broad cross section of countries, including measures of Voice and Accountability, Political stability, Government Effectiveness, Regulatory Quality, Rule of Law, and Control of Corruption. In general, the Governance index provides explanatory power to explain the capability and quality of governance from each member country. The better indicator a country has, the more it has the chance to capitalize regionalism. (f) The macroeconomic variable, which is represented by inflation, creates ambiguous expectation. High inflation might deter the formation of EAR since the very beginning, but some scholars prove the other way around. One of argument supporting the latter proposition is given by Cohen (1997) who argued that the inflationary policy (high inflation) resulting from the government action will tend to raise the obstacle to private investors, which -in turn-demand for greater integration. The loss of discretion in the fiscal and monetary policy will then reduced the risk of uncertainty. (g) Large market together with the ongoing industrialization process sums up the last aspects of EAR formation. The sheer size of the East Asian population creates not only the potential demand for the goods traded in the region, but also the supply of labor force and the low absolute level of wages. In other words, Lewis's unlimited supply of labor will persist longer in East Asia. The process will lead to an upward trend towards industrialization (value added as percentage from GDP) in the region. The trend is very important since homogeneity in industrialization among countries in the region will smooth the progress of EAR. 


\section{RESULTS AND DISCUSSION}

As Hastiadi $(2010 ; 2011)$ failed to give deep and concise analysis of the variables used, this study aims to present a comprehensive analysis of the regression. Table 1 presents the regression result from the panel data model. The railways (as a proxy of transport infrastructures)give positive coefficient for openness as expected. The percentage of growth of railways in kilometers tends to raise the net export per GDP (Openness) by 0.12 point. The result confirms the importance of transportation infrastructure to create greater possibilities for regionalism. The negative sign of the coefficient for tax describes the opposite relation between corporate tax rate and the future prospect of EAR: the higher the rate, the more it will deteriorate the EAR. The percentage of tax rate being raised tends to lower the likelihood of openness by 0.02 point. The negative sign of democracy gives the conclusion that democratic environment hampers the possibility of joining any regional trade scheme. With democracy, delivering a policy would become difficult since the government has to meet the expectation of stakeholders. Trade liberalization is surely a controversial topic that can only find political resistance from people who find themselves to be potentially affected by such policy.

Fortunately, the magnitude is not very high since one (1) point rise in the index only lowers the tendency of openness by 0.004 point. The variable of industry yields positive coefficient in which it can be concluded that the trend towards industrialization in East Asia has opened the chance of making regional grouping. One point rise in this variable will -most likely- raise the tendency of openness by 0.04 . The variable of population has not only positive, but also the biggest coefficient. Indeed, population is regarded as the most important variable that serves as a foundation towards EAR. One point rise in population will raise the likelihood of openness by 0.86 . The variable of education also shows a positive coefficient. One point rise in the coefficient will help to raise the possibility of EAR by 0.01 point. The insignificant role of inflation for EAR is expected due to the ambiguity given. Governance gives us positive and significant impact to openness. One point rise in the governance index will raise the tendency of openness by 0.26 point. This means that corruption control, voice and accountability, regulatory quality, government effectiveness, political stability, and rule of law play important roles for EAR.

Table 1.

Factors affecting openness

\begin{tabular}{|c|c|c|}
\hline \multicolumn{3}{|c|}{ Dependent Variable: OPENNES } \\
\hline $\begin{array}{c}\text { Independent } \\
\text { Variable }\end{array}$ & Coefficient & t-Statistic \\
\hline LOG(RAILWAYS) & 0.115860 & $2.059379^{* *}$ \\
\hline TAX & -0.029831 & $-3.530943^{* * *}$ \\
\hline DEMOCRACY & -0.004282 & $-2.051852^{* *}$ \\
\hline GOVERNANCE & 0.257508 & $3.860438^{* * *}$ \\
\hline INDUSTRY & 0.049930 & $4.861010^{* * *}$ \\
\hline LOG(POPULATION) & 0.863634 & $2.154852^{* *}$ \\
\hline GROSS EDUCATION & 0.011445 & $2.217493^{* *}$ \\
\hline INFLATION & -0.001545 & -0.441719 \\
\hline R-squared & 0.99251 & \\
\hline Adjusted R-squared & 0.98975 & \\
\hline
\end{tabular}

Note: Statistical significance is indicated by * $(10 \%)$, $* *(5 \%)$, and ***(1\%).

Source: Own work

\section{CONCLUDING REMARKS}

It can be said that regionalism in East Asia is driven by the market or, in other words, the bottom-up process of regionalism. Notwithstanding, the process should be matched with the top-down process which assembles leaders and policy makers into one table of negotiation. This is very important since the present scheme will mount serious problems in the future. High regional export concentration countries, high inflation and high tax rate in some ASEAN countries will pose serious threat with the absence of sound policy. Efforts to bring East Asian regionalism to its path is not like it has never been 
done before, but it has not been effectively done. The principles of a good policy are credibility, flexibility and political legitimation. Rule of law could create credibility if it is widely known and well understood by the public. With credibility, it will be easier to handle any economic turbulence with the policy instrument that is controlled by the economic authority. Credibility could function more when there is a transparent and accountable frameworkwhich strengthens political legitimation. Effective policy would merge-up if the policy makers have the ability to react promptly in every unprecedented shock. Credible policy makers are those who make the policy with respect for transparency. With the high-level transparency, any economic shock would be easily diminished. Without transparency, every policy with regards to economic target and fiscal rule would become obsolete, since the public could not compare between the target and the realization. Moreover, the political legitimation would become very important since the policies being made should reflect regional consensus. This -in turn-creates balance of power and also general responsibilities which could reduce the negative effect from the uncoordinated policy.

As Hastiadi (2011) argues, East Asian Regionalism will help the region to endure future challenges as it would lead to a more intense production network. Having said this, institution-led regionalism should replace the existing marketled regionalism. It is important not only to have East Asia as one block of countries with powerful political and economic abilities, but also to create sustainability with the shared welfare among the members. As the former Indonesian Minister of Foreign Affairs Ali Alatas said in 2001, ASEAN Plus Three is equal to peace plus prosperity, since it can contribute substantively to the achievement and maintenance of sustained and sustainable peace, stability, security and welfare in this part of the world.

From a static panel data simulation, it is found that sound transportation infrastructure, good governance, competitive taxation policy, sizeable market, good education, democracy and the trend towards industrialization are the main factors that serve as building blocks for EAR. These findings are coherent with the study conducted by the Asian Development Bank in 2006, which identifies four solid pillars for the East Asian regional cooperation and integration: (a) trade and investment; (b) money and finance; (c) infrastructure and connectivity; and (d) regional public goods.

Having identified that the factors determining regionalism in East Asia should be equally matched by actual implementation on the field by the East Asian leaders, the question then arises: will they be ready to go through the path towards regionalism?

Recent study by Capannelli in 2011 may help to answer the question:

Given the relatively high degree of global integration that characterizes Asian economies, the prosperity that can be generated by a more deeply integrated region is to be shared not only by individual Asian countries but with the entire world. Asian political leaders should be ready, however, to translate into action their declarations of intent regarding closer regionalism, create proper structures and new institutions to start a topdown approach to regional integration, as well as mobilize sufficient financial resources to ensure that future initiatives will be solid and sustainable. The 1,000 Asian opinion leaders who replied to the ADB survey are largely confident that the benefits of regionalism outweigh its costs by a substantial margin. They are part of an expanding and vibrant knowledge community which provides intellectual support to the progressive move towards closer Asian integration. The challenge facing the creation of a regional economic community is to bring this enthusiasm to the grassroots level and give new impetus to the bottom-up approach by involving the civil society in the process. 
To wrap up, EAR will enable the region to cope with the future challenges of globalization and remain internationally competitive. An integrated East Asia would lead to the advancement in economies of scale, fuller development of production networks.
As Chia (2007) stated, EAR could hold close the less developed East Asian economies, which would otherwise become marginalized as they lack the attraction of sizeable market and lack negotiating resources.

\section{REFERENCES}

1. Asian Development Bank. (2006). Regional cooperation and integration strategy. Manila: ADB.

2. Asian Development Bank. (2008). Emerging asian regionalism: A partnership for shared prosperity. Manila: ADB.

3. Baldwin, R. (1996). A Domino Theory of Regionalism. In R. Baldwin; P. Haaparanta, \& J. Kiander (Eds.), en: Expanding Membership of the EU. Cambridge, United Kingdom: Cambridge University Press.

4. Baldwin, R. (2006). Managing the noodle bowl: the fragility of east asian regionalism (CEPR Discussion Paper n. ${ }^{\circ}$ 5561). London: CEPR.

5. Bergstrand, J. H. (1989). The Generalized Gravity Equation, Monopolistic Competition, and the Factor-proportions Theory in International Trade. The review of economics and statistiscs, 71(1), 143-153.

6. Bolaky, B., \& Freund, C. (2004), "Trade Regulations and Growth Washington: World Bank", Mimeo.

7. Capannelli, G. (2011). Institutions for economic and financial integration in asia: trends and prospects (ADBI Working Paper 308). Tokyo: Asian Development Bank Institute.

8. Chia, S. Y. (2007). "Challenges and Configurations of a Region-wide FTA in East Asia". FONDAD Conference presentation.

9. Cohen, B. J. (1997). The Political Economy of Currency Regions. In H. Milner \& Edward Mansfield (Eds.), The Political Economy of Regionalism. New York: Columbia University Press.

10. Dell ' Ariccia, G. (1999). Exchange Rate Fluctuations and Trade Flows: Evidence from the European Union. IMF Staff Papers, 46(3), 315-334.

11. Drysale, P. (2006, March 31). Regionalism in asia and the pacific and an asian economic community (Workshop paper). New Delhi: ICRIER.

12. Dutt, P., \& Mitra, D. (2002). Endogenous trade policy through majority voting: an empirical investigation. Journal of International Economics, 58(1), 107-33.

13. Feng, Y., \& Gaspare M. G. (2003). Regional Integration and Domestic Institutional Homogeneity: a comparative analysis of regional integration in the Americas, Pacific Asia and Western Europe. Review of International Political Economy, 10(1), 223-230.

14. Fisman, R. J. \& Sarria-Allende, V. (2004). Regulation of entry and the distortion of industrial organization (Working Paper 10929). Massachusetts: NBER. 
15. Geddes, B. (1995). Challenging the Conventional Wisdom. In Economic reform and democracy. Diamond, L. Eु Plattner, M. (Eds.). Baltimore: Johns Hopkins.

16. Grossman, G. M., \& Helpman, E. (1994). Protection for Sale. The American Economic Review, 84(4), 833-850.

17. Hastiadi, F. F. (2011). East Asian Regionalism: The Need for ASEAN+3. Journal of Global Business and Economics, 3, 31-56.

18. Hastiadi, F. F. (2011). Regionalism in East Asia: The Role of North East Asian Nations. American Journal of Economics and Business Administration, 3(2), 242-253.

19. Hastiadi, F. F. (2010). Making East Asian Regionalism Works. Buletin Ekonomi Moneter danPerbankan, 13, 107-128.

20. Jones RW, Kierzkowski H. (2001). A Framework for Fragmentation. In: Arndt SW, Kierzkowski H. (eds), Fragmentation: New Production Patterns in the World Economy. Oxford: University Press.

21. Kaufmann, D., Kraay, A., \& Mastruzzi, M. (2008). Governance Matters III: Governance Indicators for 1996-2002 (Working paper). World Bank Policy Research Department.

22. Kawai, M. (2007). Evolving economic architecture in east asia (Discussion Paper n. ${ }^{\circ 4}$ ). Tokyo: ADB Institute.

23. Kawai, M. (2005). East Asian Economic Regionalism: Progress and Challenges. Asian Economics, 16(1), 29-55.

24. Kawai, M., \& Ganeshan, W. (2007). Regionalism as an engine of multilateralism: a case for a single east asian FTA (Working Paper series on Regional Economic Integration n. ${ }^{\circ}$ 14). Tokyo: ADB Institute.

25. Klapper, L., Laeven, L, \& Raghuram, R. (2004). Business environment and firm entry: evidence from international data (Working paper 10380). Massachsetts: NBER.

26. Limão, N., \& Venables, A. (2001). Infrastructure, Geographical Disadvantage, Transport Costs and Trade. World Bank Economic Review, 15, 451-479.

27. Love, J., \& Ramesh, C. (2004). An Index of Openness and its Relationship with Growth in India. The Journal of Developing Areas, 38, 37-54.

28. Matyas, L. (1997). Proper Econometric Specification of the Gravity Model. World Economy, 20(3): 363-368.

29. Mayer, W. (1984). Endogenous Tariff Formation. American Economic Review, 74(5), 970-985. 
30. Milner, H. V., \& Kubota, K. (2005). Why the move to free trade? Democracy and trade policy in the developing countries. International Organization, 59(1), 107-143.

31. Mitra, D., Thomakos D., \& Ulubasoglu, M. (2002). Protection for Sale in a Developing Country: Democracy vs. Dictatorship. Review of Economics and Statistics, 84(3), 497-508.

32. Nachrowi, D. (2008). Ekonometrika untuk analisa ekonomi dan keuangan. Econometrics for Economic and financial analysis. Faculty of Economics, University of Indonesia.

33. Nuroglu, (2010). The Impact of Population on Bilateral Trade Flows in the Case of OIC, (Working Paper). International University of Sarajevo.

34. Olson, M. (1982). The rise and decline of nations: Economic growth, stagflation, and social rigidities. New Haven: Yale University Press.

35. Petri, P. (2006). Is Asia becoming more interdependent? Journal of Asian Economics, 17(3), 381-394.

36. Smith, A. (1776). An Inquiry into the Nature and Causes of the Wealth of Nations. University Of Chicago Press.

37. Soesastro, H. (2006). Regional Integration in East Asia: Achievements and future prospects. Asian Economic Policy Review, 1(2), 215-235.

38. Tamura, R. (1995). Regional economies and market integration. Journal of Economic Dynamics and Control, 20(5), 825-845.

39. UNESCAP. (2010). What is Good Governance? Poverty and Development Division Article.

40. Yeaple, S., \& Golub, S. (2002). "International Productivity Differences, Infrastructure, and Comparative Advantage". Mimeo.

41. Watanabe, Y. (2008). "Economic Partnership Agreement (EPA) of Japan and Economic Integration in Northeast Asia" (Academic presentation). Graduate School of Media and Governance, Keio University.

42. Wilson, J., Mann, C. \& Otsuki, T. (2005), Assessing the Benefits of Trade Facilitation: A Global Perspective. In The World Economy, pp. 841-871. World Trade Organization, WTO. 